\title{
Toxicity and Subcellular Fractionation of Yttrium in Three Freshwater Organisms: Daphnia magna, Chironomus riparius, and Oncorhynchus mykiss
}

Pierre-Yves Cardon, ${ }^{\dagger}$ Gaëlle Triffault-Bouchet, ${ }^{\ddagger}$ Antoine Caron, ${ }^{\dagger}$ Maikel Rosabal, ${ }^{\S}$ Claude Fortin, ${ }^{\| \odot}$ and Marc Amyot* ${ }^{*}+$ (1)

†Département de Sciences Biologiques, GRIL, Université de Montréal (UdeM), Pavillon Marie-Victorin, 90 Avenue Vincent-d’Indy, Montréal, Québec H3C 3J7, Canada

${ }^{\ddagger}$ Division de l'écotoxicologie et de l'évaluation du risque, Centre d'expertise en Analyse Environnementale du Québec (CEAEQ), 2700 rue Einstein, Québec, Québec G1P 3W8, Canada

${ }^{\S}$ Département des Sciences Biologiques, GRIL, Université du Québec à Montréal (UQAM), 141 Avenue du président-Kennedy, Montréal, Québec H2X 1Y4, Canada

"Centre Eau Terre Environnement (INRS-ETE), Institut National de la Recherche Scientifique, 490 rue de la Couronne, Québec, Québec G1K 9A9, Canada

Supporting Information

ABSTRACT: The demand for rare earth elements (REEs) has increased since the 1990s leading to the development of many mining projects worldwide. However, less is known about how organisms can handle these metals in natural aquatic systems. Through laboratory experiments, we assessed the chronic toxicity and subcellular fractionation of yttrium (Y), one of the four most abundant REEs, in three freshwater organisms commonly used in aquatic toxicology: Daphnia magna, Chironomus riparius, and Oncorhynchus mykiss. In bioassays using growth as an end point, $C$. riparius was the only organism showing toxicity at $\mathrm{Y}$ exposure concentrations close to environmental ones. The lowest observable effect concentrations (LOECs) of Y assessed for D. magna and $O$. mykiss were at least 100 times higher than the $\mathrm{Y}$ concentration in natural freshwater. A negative correlation between $\mathrm{Y}$ toxicity and water hardness was observed for D. magna. When exposed to their respective estimated LOECs, D. magna bioaccumulated 15-45 times more $Y$ than the other two organisms exposed to their own LOECs. This former species sequestered up to $75 \%$ of $\mathrm{Y}$ in the $\mathrm{NaOH}$-resistant fraction, a putative metal-detoxified subcellular fraction. To a lesser extent, C. riparius bioaccumulated $20-30 \%$ of $\mathrm{Y}$ in this detoxified fraction. In contrast, the $\mathrm{Y}$

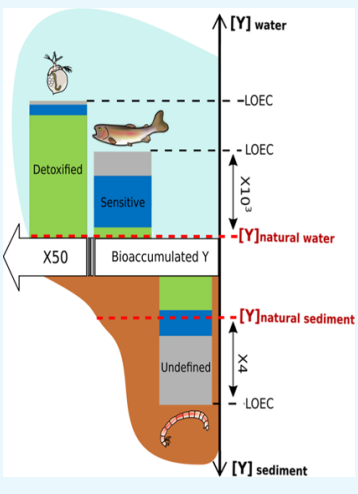
subcellular distribution in $O$. mykiss liver did not highlight any notable detoxification strategy; Y was accumulated primarily in mitochondria (ca. 32\%), a putative metal-sensitive fraction. This fraction was also the main sensitive fraction where $\mathrm{Y}$ accumulated in C. riparius and D. magna. Hence, the interaction of $Y$ with mitochondria could explain its toxicity. In conclusion, there is a wide range of subcellular handling strategies for $Y$, with $D$. magna accumulating high quantities but sequestering most of it in detoxified fractions, whereas $O$. mykiss tending to accumulate less $\mathrm{Y}$ but in highly sensitive fractions.

\section{INTRODUCTION}

The global demand for rare earth elements (REEs) is increasing since the $1990 \mathrm{~s}^{1,2}$ as a result of their use in almost all activity sectors, from high technology and electrification of transport to medicine and agriculture. ${ }^{3}$ Therefore, contamination of water ecosystems by these metals from mining activity, agriculture, and the disposal of urban and electronic wastes is of growing concern for environmental protection agencies. Contamination of freshwater ecosystems by REEs has already been reported. ${ }^{4,5}$

The REE complexes formed with carbonates and organic matter are the dominant species of REEs in solution. ${ }^{6}$ These metals also have a strong affinity for clays ${ }^{7}$ and usually the solubility of REEs is very low. ${ }^{8}$ Weltje et al. ${ }^{9}$ have reported that 99\% of the REEs present in aquatic environments are either related to a suspended matter or sediment. Dissolved concentrations of REEs in these environments are therefore often very low, ranging from 2.9 to $714 \mathrm{ng} \mathrm{L}^{-1}$ for $\mathrm{Ce}$ and 0.04-7 $\mathrm{ng} \mathrm{L}^{-1}$ for Lu. ${ }^{10}$

Some studies on REE toxicity in freshwater organisms concluded that even if REEs are a group of metals with similar chemical properties, toxicity differences have been observed between heavy REEs (HREEs) and light REEs (LREEs). ${ }^{11,12}$ Among the four most abundant REEs, yttrium (Y) is the only one classified as a HREE. Nevertheless, to our knowledge, in comparison with lanthanum $(\mathrm{La})$, cerium $(\mathrm{Ce})$, and neo-

Received: April 30, 2019

Accepted: July 31, 2019

Published: August 15, 2019 
Table 1. Sublethal Toxicity (in \% of Relative Size, Mean \pm CV), Lethal Toxicity (in Survival Rate), and Bioaccumulation (mg $\mathrm{kg}^{-1} \mathrm{ww}$, Mean $\pm \mathrm{CV}$ ) of $\mathrm{Y}$ for Each Organism in Whole at the End of the Bioassays

\begin{tabular}{|c|c|c|c|c|c|c|c|c|}
\hline & \multicolumn{5}{|c|}{ yttrium exposure } & \multicolumn{2}{|c|}{ toxicity } & \multirow{2}{*}{$\begin{array}{l}\text { bioaccumulation } \\
\text { mg Y kg }{ }^{-1} \text { ww }\end{array}$} \\
\hline & $n$ & medium & $\begin{array}{c}\text { hardness } \\
\left(\mathrm{mg} \mathrm{L}^{-1} \text { of } \mathrm{CaCO}_{3}\right)\end{array}$ & {$[\mathrm{Y}]$} & units & $\begin{array}{l}\text { relative animal } \\
\quad \text { size }(\%)^{\&}\end{array}$ & $\begin{array}{l}\text { survival rate } \\
(\%)\end{array}$ & \\
\hline \multirow[t]{5}{*}{ D. magna } & 10 & artificial water & 130 & 0.2 & $\mu \mathrm{g}$ dissolved $\mathrm{Y} \mathrm{L}^{-1}$ & $100 \pm 13^{\mathrm{a}}$ & 100 & $0.022 \pm 29 \%^{\mathrm{a}}$ \\
\hline & & & & 202 & & $98 \pm 22^{a}$ & 100 & $45 \pm 41 \%^{\mathrm{a}, \mathrm{b}}$ \\
\hline & & & & $400^{\#}$ & & $94 \pm 13^{a}$ & 90 & $33 \pm 21 \%^{\mathrm{a}, \mathrm{b}}$ \\
\hline & & & & 798 & & $74 \pm 9^{b}$ & 80 & $55 \pm 66 \%^{\mathrm{b}}$ \\
\hline & & & & 1187 & & & 0 & \\
\hline \multirow[t]{4}{*}{ C. riparius } & 30 & Y-spiked natural & 45 & 15 & $\mathrm{mg}$ total $\mathrm{Y} \mathrm{kg}^{-1}$ of $\mathrm{dw}$ & $100 \pm 2^{a}$ & 92 & $0.12 \pm 28 \%^{\mathrm{a}}$ \\
\hline & & sediment & & 53 & & $90 \pm 5^{\mathrm{b}}$ & 83 & $0.39 \pm 20 \%^{\mathrm{a}}$ \\
\hline & & & & 99 & & $91 \pm 0.2^{b}$ & 99 & $0.78 \pm 13 \%^{b}$ \\
\hline & & & & 465 & & $82 \pm 2^{c}$ & 72 & $2.1 \pm 10 \%^{\mathrm{c}}$ \\
\hline \multirow[t]{5}{*}{ O. mykiss } & 9 & artificial water & 45 & $0.1^{(0)}$ & $\mu \mathrm{g}$ dissolved & $100 \pm 0^{\mathrm{a}}$ & 100 & $0.001 \pm 56 \%^{\mathrm{a}}$ \\
\hline & & & & $36^{(250)}$ & Y L & $96 \pm 0.1^{\mathrm{a}, \mathrm{b}}$ & 100 & $2.0 \pm 21 \%^{\mathrm{b}}$ \\
\hline & & & & $79^{(500)}$ & & $91 \pm 0.04^{b}$ & 100 & $3.1 \pm 16 \%^{\mathrm{c}}$ \\
\hline & & & & $454^{(1000)}$ & & & 0 & \\
\hline & & & & $1110^{(2000)}$ & & & 0 & \\
\hline
\end{tabular}

${ }^{\#} \mathrm{Y}$ nominal concentration (Y-dissolved measurements were not performed at this exposure level). ${ }^{\text {\& }}$ The relative body size is the ratio of the average body size for a given exposure concentration divided by that measured for the controls (lowest exposure concentration). Different letters indicate a significant difference of relative body size or Y bioaccumulation for a given organism among Y exposure level (ANOVA, followed by Tukey's pairwise comparison test; $p<0.05)$. *The dissolved $\mathrm{Y}$ concentrations over the 28-day exposure of $O$. mykiss are given in the Supporting Information, Table S5. Because these values showed strong variations, we also indicate the nominal values here and use these nominal values for the discussion.

dymium (Nd), Y toxicity has received less attention so far. Yet, $\mathrm{Y}$ is needed in many high-technology applications such as optical fiber and light-emitting diodes. ${ }^{3}$ Furthermore, a recent study reported cytotoxicity linked to $\mathrm{Y}^{13}$

Animal sensitivity toward metals and their handling strategies depend, among others, on the considered metal and species. Animals can develop different combinations of strategies based on the regulation of metal assimilation, excretion, and depuration. They can also handle metal contamination at a subcellular level. ${ }^{14}$ Indeed, metal assimilated by an organism is partitioned between subcellular components that can be operationally isolated through procedures involving centrifugation, heating, and chemical digestion. ${ }^{15,16}$ Some of these components such as mitochondria and heat-denatured proteins (HDP) such as enzymes appear sensitive to metals, and the accumulation of metal in these metal-sensitive fractions (MSF) may be related to their malfunction. On the contrary, metals accumulated in other subcellular components, such as heat-stable proteins (HSP; also called metallothionein-like proteins), and metal-rich granules (MRG), such as lysosomal residual and phosphatebased bodies which are included in the $\mathrm{NaOH}$-resistant fraction, are considered by many authors as metal-detoxified fractions (MDF). ${ }^{17}$ The proportion of bioaccumulated metals recovered between MDF and MSF may explain the differences in sensitivity to metal accumulation between organisms for a given metal. $^{17,18}$

Hypotheses and concepts related to metal thresholds for these two kinds of fractions have been investigated in ecotoxicology since 2003. ${ }^{15}$ For example, the concept of "spillover" assumes that a given metal only begins to accumulate in MSF when its concentration in MDF exceeds a threshold. ${ }^{19}$ Similarly, the tissue residue approach considers that adverse toxicological effects occur in organisms when a metal reaches a concentration threshold on MSF. ${ }^{20}$

This study aims (1) to evaluate $\mathrm{Y}$ chronic toxicity to three species commonly used in aquatic toxicology-the water flea ( Daphnia magna), the harlequin fly (Chironomus riparius), and the rainbow trout (Oncorhynchus mykiss) - and to define the lowest observable effect concentrations (LOECs) and (2) to determine Y subcellular distribution in each organism along exposure gradients including these LOECs. LOECs are compared with the existing data on $\mathrm{Y}$ and REE concentrations in freshwater ecosystems to better understand the actual ecotoxicological risk induced by this metal on the environment. Also, the Y subcellular detoxication strategy of each organism is discussed in light of their strategies for other metals.

\section{RESULTS AND DISCUSSION}

Toxicity and Bioaccumulation in the Three Aquatic Animals Studied. The exposure conditions, including $\mathrm{Y}$ concentrations, in the D. magna, C. riparius, and O. mykiss bioassays are presented in the Supporting Information, Tables S3, S4, and S5, respectively.

Daphnia magna. Yttrium Toxicity to D. magna. After 7 days of exposure to $Y$, a decrease of $D$. magna relative size as a function of exposure was observed at a hardness of $130 \mathrm{mg} \mathrm{L}^{-1}$ of $\mathrm{CaCO}_{3}$ (Table 1). Indeed, a significant loss of $26 \%$ of $D$. magna relative size was measured at $798 \mu \mathrm{g} \mathrm{L}^{-1}$, corresponding to the LOEC of this test. With respect to mortality, no daphnids survived an exposure to $1187 \mu \mathrm{g} \mathrm{L}^{-1} \mathrm{Y}$ (Table 1). Both mortality and LOECs were reached at lower exposure levels for the tests conducted in water with lower hardness (Supporting Information, Figure S4). For example, 100\% mortality was reached for an Y exposure level of $706 \mu \mathrm{g} \mathrm{L}^{-1}$ at $90 \mathrm{mg} \mathrm{L}^{-1}$ of $\mathrm{CaCO}_{3}$. In addition, a significant decrease of $D$. 
magna size was observed from $191 \mu \mathrm{g} \mathrm{L}^{-1}$ of $\mathrm{Y}$ at $66 \mathrm{mg} \mathrm{L}^{-1}$ of $\mathrm{CaCO}_{3}$ (Supporting Information, Figure S4). The negative correlation between water hardness and $\mathrm{Y}$ toxicity observed has also been reported for other REEs from bioassays performed on Hyalella azteca, ${ }^{11,24}$ Daphnia carinata, ${ }^{25}$ and Daphnia pulex. ${ }^{24}$ Depending on hardness conditions, the LOEC for D. magna ranged from 191 to $798 \mu \mathrm{g} \mathrm{L}^{-1}$ of dissolved Y (Table 1 and Supporting Information, Figure S4). For comparison, $\mathrm{Ma}$ et al. ${ }^{26}$ have reported an LOEC close to $400 \mu \mathrm{g} \mathrm{L}^{-1}$ of dissolved Ce for D. magna growth at a hardness of $252 \mathrm{mg} \mathrm{L}^{-1}$ of $\mathrm{CaCO}_{3}$. Also, a significant mortality of $D$. carinata was observed by Barry and Meehan over a 6-day exposure to $39 \mu \mathrm{g} \mathrm{La} \mathrm{L}{ }^{-1}{ }^{25}$ Both studies were performed in water with higher hardness than our maximal one, $130 \mathrm{mg} \mathrm{L}^{-1}$ of $\mathrm{CaCO}_{3}$. This could suggest that HREEs, similar to $\mathrm{Y}$, are less toxic than LREEs. This trend had already been reported for $H$. azteca. ${ }^{11}$ Nonetheless, other authors measured a positive correlation between REE toxicity and their atomic number, ${ }^{27}$ lutecium being the most toxic. Thus, further investigations would be required to compare HREE and LREE toxicity.

The LOECs measured in our study and others mentioned before are far higher than the REE concentrations which have been measured in aquatic ecosystems. For instance, Amyot et al. $^{28}$ have reported an average concentration for the sum of REE of $0.9 \mu \mathrm{g} \mathrm{L}^{-1}$ and $0.1 \mu \mathrm{g} \mathrm{L}^{-1}$ of $\mathrm{Y}$ in 14 lakes of southern Quebec (Canada). Weltje et al. ${ }^{9}$ have measured for the sum of REE dissolved concentrations ranging from $0.003(\mathrm{Lu})$ to 0.7 (Ce) $\mu \mathrm{g} \mathrm{L}^{-1}$ in several freshwater ecosystems. Finally, in the Rhine, a river contaminated by anthropogenic $\mathrm{La}$ and $\mathrm{Gd},{ }^{4}$ a dissolved total REE level of $0.21 \mu \mathrm{g} \mathrm{L}^{-1}$ was recorded, which is 1000 times lower than our LOEC.

Yttrium Bioaccumulation in D. magna. With respect to bioaccumulation, with the control Y exposure level $(0.2 \mu \mathrm{g}$ $\mathrm{L}^{-1}$ ) being excluded, the $D$. magna $\mathrm{Y}$ content ranged from $33 \pm$ 21 to $45 \pm 66 \mathrm{mg} \mathrm{Y} \mathrm{kg}^{-1} \mathrm{ww}$, but no trend was observed with the exposure concentration (Table 1). This bioaccumulation is 11-141 times higher than the ones measured for the other two organisms. Such high bioaccumulation values for an REE in zooplankton have already been observed before in the laboratory, ${ }^{29}$ but they are more than 2 orders of magnitude higher than those reported on average in the field. For instance, the mean $\mathrm{Y}$ concentrations in temperate ${ }^{28}$ and $\operatorname{arctic}^{30}$ freshwater zooplankton reached $0.2 \pm 0.1$ and $9.2 \mathrm{mg}$ $\mathrm{kg}^{-1} \mathrm{dw}$, respectively.

Chironomus riparius. Yttrium Toxicity to C. riparius. A significant decrease of $10-18 \%$ of $C$. riparius body relative size was measured as a function of $\mathrm{Y}$ concentration in the sediments (Table 1). At the maximal level of $\mathrm{Y}$ exposure, $465 \mathrm{mg} \mathrm{kg}^{-1}$, the survival rate only reached $72 \pm 1 \%$, our lowest value for this bioassay (Table 1). Few studies have tested the REE toxicity as a function of sediment concentrations, and none on chironomids. An LOEC of 50 $\mathrm{mg} \mathrm{La} \mathrm{kg}{ }^{-1}$ sediment for Caenorhabditis elegans, a value close to our LOEC for C. riparius $\left(53 \mathrm{mg} \mathrm{kg}^{-1} \mathrm{dw}\right)$, was reported. ${ }^{31}$ In addition, a Microtox test performed with sediments from Northern Quebec ${ }^{32}$ determined the $\mathrm{IC}_{10}$ value for total REE (inhibition concentrations causing a $10 \%$ reduction in the end point) ranging from 0.45 to $48 \mathrm{mg} \mathrm{kg}$.

In natural environment, the concentrations of REEs in sediments that have already been measured can be very close to these ecotoxicological values. Concentrations ranging from 63 to 253 of $\mathrm{mg} \mathrm{kg}^{-1} \mathrm{dw}$ for Ce, the most abundant REE, and up to $39 \mathrm{mg} \mathrm{kg}^{-1} \mathrm{dw}$ for $\mathrm{Y}$ in the sediments from 26 freshwater ecosystems sampled around the world were reported. ${ }^{33}$ Also, averages of $154 \pm 69$ and $18 \pm 6 \mathrm{mg} \mathrm{kg}^{-1} \mathrm{dw}$, of total REE and $\mathrm{Y}$, respectively, were measured in the sediments from temperate lakes. ${ }^{28}$ However, note that the dissolved $\mathrm{Y}$ concentration in water measured at our LOEC in sediment (2.2 $\pm 0.7 \mu \mathrm{g} \mathrm{L}^{-1}$; Supporting Information, Table S4) remained around 20 times higher than the concentrations reported in freshwater ecosystems. ${ }^{28,30}$

Yttrium Bioaccumulation in C. riparius. Unlike D. magna, a significant increase in $\mathrm{Y}$ accumulation by $C$. riparius was measured as a function of exposure concentrations. Yttrium accumulated after 10 days ranged from $120 \pm 34 \mu \mathrm{g} \mathrm{kg}^{-1} \mathrm{ww}$ at the lowest exposure level to $2088 \pm 209 \mu \mathrm{g} \mathrm{kg}^{-1}$ ww at the highest one (Table 1).

Bioaccumulation values close to ours have been observed in natural freshwater ecosystems. Ranges of total REE levels in benthic invertebrates from arctic lakes ${ }^{30}$ and temperate lakes ${ }^{28}$ of 0.22-42 (mean: $4.6 \pm 12$ ) and 0.47-37 (mean: $4.6 \pm 5.7$ ) $\mathrm{mg} \mathrm{kg}{ }^{-1} \mathrm{dw}$, respectively, were reported. Furthermore, Y reached on average $0.61 \pm 0.54 \mathrm{mg} \mathrm{kg}^{-1} \mathrm{dw}$ in chironomids from temperate lakes. ${ }^{28}$ These bioaccumulation values are expressed by $\mathrm{dw}^{-1}$, whereas ours are in $\mathrm{ww}^{-1}$. To be converted in $\mathrm{dw}$, our bioaccumulation values should be at least multiplied by $4 .{ }^{34}$ However, even with this factor, they remain close to the ones measured in natural environment.

Oncorhynchus mykiss. Yttrium Toxicity to O. mykiss. When exposed to a nominal exposure level of $1000 \mu \mathrm{g} \mathrm{L}^{-1}$, no trout survived more than 10 days (Table 1). Moreover, a significant decrease in the relative body size at the end of the bioassay was observed at $500 \mu \mathrm{g} \mathrm{L}^{-1}$ (Table 1). At this exposure level, a loss of $9 \pm 4 \%$ of $O$. mykiss body size was determined (Table 1).

Watson-Leung ${ }^{35}$ observed no toxic effect of La on O. mykiss exposed for $96 \mathrm{~h}$ up to a dissolved concentration of $63.3 \mathrm{mg}$ $\mathrm{L}^{-1}$. This threshold concentration reached $0.13 \mathrm{mg} \mathrm{L}^{-1}$ in a 96 $\mathrm{h}$ bioassay for the crimson-spotted rainbow fish, Melanotaenia duboulayi. ${ }^{36}$ This last threshold is not far from our LOEC, which is about $0.08 \mathrm{mg} \mathrm{L} \mathrm{L}^{-1}$ of dissolved Y (Supporting Information, Table S5).

Yttrium Bioaccumulation in O. mykiss. Similar to $C$. riparius and unlike D. magna, O. mykiss bioaccumulated more $\mathrm{Y}$ with increasing $\mathrm{Y}$ exposure. The $\mathrm{Y}$ levels in this organism at the end of the bioassay ranged from $0.001 \pm 56$ to $3.1 \pm 16 \% \mathrm{mg}$ $\mathrm{kg}^{-1}$ ww (Table 1). The exposure concentration for this maximal value corresponds to our LOEC: $500 \mu \mathrm{g} \mathrm{L}^{-1}$.

To our knowledge, the high bioaccumulation value of REE measured in our whole fish has never been observed in natural freshwater ecosystems and is at least 5 times higher than those reported on the field. For instance, among tissues from 10 freshwater fish species from a reservoir in the state of Washington, a maximum REE level of $0.69 \mathrm{mg} \mathrm{kg}^{-1}$ ww of Catostomus catostomus including $0.057 \mathrm{mg} \mathrm{kg}^{-1}$ ww of $\mathrm{Y}$ was reported. ${ }^{37}$ Furthermore, the ranges of 10 times lower bioaccumulation values of REE were assessed in four freshwater fish species sold in 17 cities of China ${ }^{38}$ (from 0.034 to $0.038 \mathrm{mg} \mathrm{kg}^{-1} \mathrm{ww}$ ) and in 6 from Canadian temperate lakes ${ }^{28}$ (from 0.70 to $59 \mu \mathrm{g} \mathrm{REE} \mathrm{kg}^{-1} \mathrm{dw}$ including 0.041 to $\left.7.4 \mu \mathrm{g} \mathrm{Y} \mathrm{kg}^{-1} \mathrm{dw}\right)$.

Yttrium Subcellular Fractionation by Species. Daphnia magna. For all Y exposure levels, more than $70 \%$ of $\mathrm{Y}$ was recovered in the $\mathrm{NaOH}$-resistant fraction of $D$. magna with an average $\mathrm{Y}$ content of $38 \pm 14 \mathrm{mg} \mathrm{kg}^{-1} \mathrm{ww}$ in this fraction (Figure 1). In addition, this fraction was the only one above 


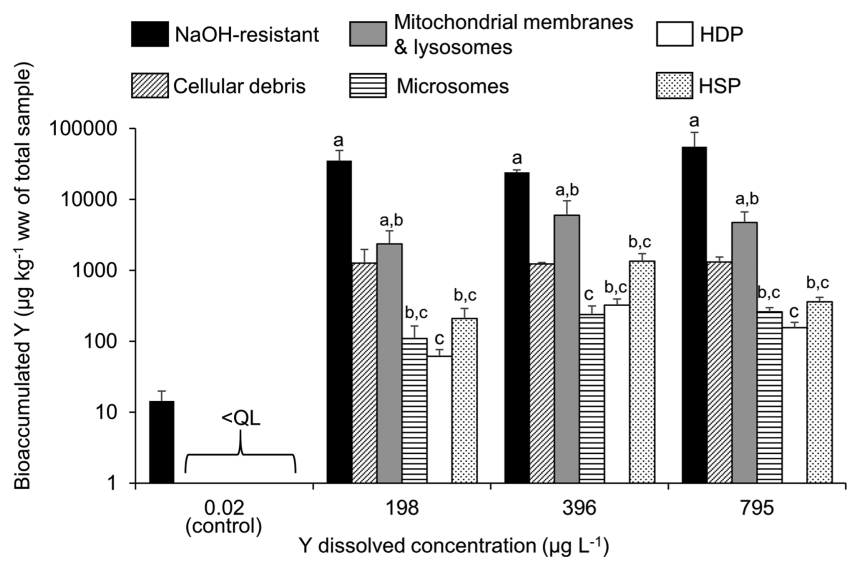

Figure 1. Bioaccumulation of $Y$ in each validated fraction of $D$. magna (mean $\pm \mathrm{SD}$; in $\mu \mathrm{g} \mathrm{kg}^{-1} \mathrm{ww}$ of the total sample; $n=3$ ) following the exposure level. Different letters indicate a significant difference of $\mathrm{Y}$ accumulation among fractions for a given $\mathrm{Y}$ exposure level (ANOVA; $F(5,12)=18,92$, and 8 for exposure at 198,396 , and $795 \mu \mathrm{g} \mathrm{L}^{-1}$, respectively; followed by Tukey's pairwise comparison test, $p<0.05$ ). The absence of a letter indicates that there is no significant difference. QL: $8 \mathrm{ng} \mathrm{L^{-1 }}$.

our quantification limit (QL) $\left(0.022 \pm 0.006 \mathrm{mg} \mathrm{Y} \mathrm{kg}^{-1} \mathrm{ww}\right)$ for our control. The fraction containing mitochondrial membranes and lysosomes contained $6-18 \%$ of the total amount of Y (Figure 1). Overall, the Y subcellular distribution in D. magna appears constant over our exposure range. Note that in a complementary experiment for a short exposure period of $24 \mathrm{~h}$ (Supporting Information, Figure S6), a significant decline of the proportion of $\mathrm{Y}$ in organelles (mitochondrial membranes, lysosomes, and microsomes), from $21 \pm 6$ to $7 \pm 1 \%$, concomitantly with an increase in the $\mathrm{NaOH}$-resistant fraction, from $62 \pm 13$ to $88.1 \pm 0.1 \%$, was observed over the exposure range.

The accumulation of $\mathrm{Y}$ mainly in $\mathrm{NaOH}$-resistant fraction, a putative MDF, may explain why $D$. magna was able to bioaccumulate $\mathrm{Y}$ at concentrations far higher than the two other organisms. ${ }^{18}$ Few other studies have reported metal fractionation in daphnids, and $\mathrm{Y}$ is the first metal found to be mainly sequestered in daphnid $\mathrm{NaOH}$-resistant fraction. In contrast, around $28 \%$ of $\mathrm{Ni}^{39}$ and less than $1 \%$ of $\mathrm{Zn}^{40}$ were found in this fraction in previous studies. Nevertheless, an accumulation of more than $70 \%$ of a metal in the $\mathrm{NaOH}$ resistant fraction has been previously reported in other crustaceans- $\mathrm{U}$ in Procambarus clarkii ${ }^{41}$ and $\mathrm{Pb}$ in Gammarus fossarum ${ }^{42}$-but also in bivalves: $\mathrm{Cd}$ and $\mathrm{Ag}$ in Saccostrea cucullata, ${ }^{43} \mathrm{Cr}$ and $\mathrm{Fe}$ in Scrobicularia plana, ${ }^{44} \mathrm{Zn}$ and $\mathrm{Cu}$ in Pyganodon grandis, ${ }^{19}$ and $\mathrm{Pb}$ in Dosinia exoleta. ${ }^{45}$

The $\mathrm{NaOH}$-resistant fraction is presumed to contain organelles such as MRG that are defined as detoxified. Nevertheless, we have strong suspicions that it also contains debris from the chitinous exoskeleton of $D$. magna. Indeed, several authors have used a similar $\mathrm{NaOH}$ treatment to isolate Daphnia exoskeletons from its soft tissues. ${ }^{46}$ Also, it is well known that the REE present a strong antagonism with $\mathrm{Ca}$, which accumulates in crustacean exoskeleton in the form of calcium carbonate. ${ }^{47,48}$ The REE can be absorbed at Ca uptake sites and can inhibit calcium ion channels, with stronger inhibition being reported for REE with shorter ion radius, such as $\mathrm{Y}^{49}$ Moreover, analysis of the distribution of REEs in crabs (Ucides cordatus) revealed a higher accumulation in the shells ${ }^{50}$ and has already led authors to assume a replacement of Ca during moulting. The same assumption could be made for $D$. magna. It could explain why there is no apparent relationship between exposure concentration and bioaccumulation in $D$. magna as well as its capacity to accumulate relatively more $\mathrm{Y}$ than the other model organisms.

Several authors have reported that the proportion of a given metal accumulated in MDF increased with the level of exposure to that metal. ${ }^{51}$ This would suggest a progressive subcellular detoxification of the metal in response to its level of exposure. Although this mechanism was not observed during the 7-day exposure to Y (Figure 1), it was present in the 24-h exposure of $D$. magna to $\mathrm{Y}$ (Supporting Information, Figure S6).

Even if the classification of lysosomes in either MDF or MSF can be debated, it is well established that mitochondria belong to the sensitive group. Similar to $\mathrm{Y}$, the mitochondrial and organelle fraction was the MSF in which a higher relative metal proportion was found in D. magna with $40 \%$ for $\mathrm{Zn}^{40}$ and 5 and $8 \%$ for $\mathrm{Ni}$ and $\mathrm{Tl}$, respectively. ${ }^{39}$ It could suggest that the metal toxicity mechanism for this crustacean, in general, is related to an interference in its mitochondrial functions.

Chironomus riparius. Cellular debris fraction was the main one that bioaccumulated the $\mathrm{Y}$ in C. riparius (Figure 2). From

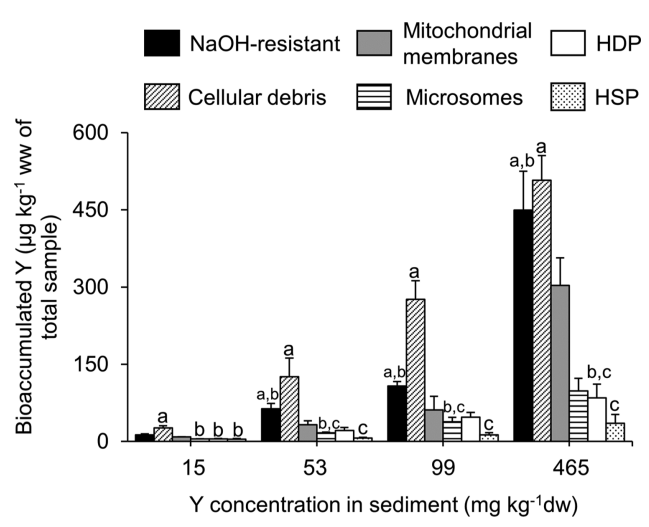

Figure 2. Bioaccumulation of $\mathrm{Y}$ in each validated fraction of $C$. riparius (mean $\pm \mathrm{SD}$; in $\mu \mathrm{g}$ of $\mathrm{Y}$ in the fraction per kilogram of the total wet weight of the sample; $n=3$ ) as a function of exposure concentration. Different letters indicate a significant difference of $Y$ accumulation among fractions for a given $Y$ level exposure (ANOVA; $F(5,12)=46,23,73$, and 59 for exposure at $15,53,99$, and $465 \mathrm{mg}$ $\mathrm{kg}^{-1}$, respectively; followed by Tukey's pairwise comparison test, $p<$ 0.05 ). The absence of a letter indicates that there is no significant difference.

34 to $51 \%$ of $\mathrm{Y}$ was recovered in this fraction through our exposure range. Like D. magna, $\mathrm{NaOH}$-resistant and mitochondrial membrane fractions are, respectively, the first putative MDF and MSF that bioaccumulated the $\mathrm{Y}$ in $\mathrm{C}$. riparius cells (Figure 2). The first fraction contained from 20 to $30 \%$ of $\mathrm{Y}$ and the second from 11 to $20 \%$. Along our exposure range, $\mathrm{Y}$ distribution between fractions appeared stable, except for our maximal exposure level (465 $\mathrm{mg} \mathrm{kg}^{-1} \mathrm{dw}$ ). Indeed, between this exposure level and the previous one $\left(93 \mathrm{mg} \mathrm{kg}^{-1}\right.$ $\mathrm{dw}$ ), less $\mathrm{Y}$ was found in the cellular debris fraction while more was found in both $\mathrm{NaOH}$-resistant and the mitochondrial membrane fractions. Y levels increased 4- and 5-folds in these latter fractions between these two exposure levels versus only twice for cellular debris (Figure 2). 
Strategies of Y subcellular detoxification in C. riparius seem to differ from that of other metals already assessed for this species. If less than $15 \%$ of $Y$ was found in the HDP and in the HSP fractions over our exposure range, these two fractions appeared as the top MSF and MDF, respectively, for the accumulation of $\mathrm{Ni}^{52} \mathrm{Se},{ }^{53} \mathrm{Cd}^{54}$ and $\mathrm{Hg}^{55}$ in Chironomus sp. However, most of the Se and $\mathrm{Ni}$ were found in cellular debris, with more than a third of the relative distribution in C. riparius. This fraction should therefore be considered important to understand metal subcellular management in this species. Toxicological significance of metal accumulation in cellular debris is not currently well defined and most authors do not include this fraction while interpreting metal subcellular distribution. ${ }^{56}$ Nonetheless, others suggest that a metalsensitive compartment integrating the cellular debris may be more relevant. ${ }^{57}$ Furthermore, it was established that metal binding to nucleic acid inside the nucleus (found in the debris fraction) could modify both transcription and DNA replication and induce genotoxicity. ${ }^{58}$ Also, Huang et al. ${ }^{59}$ have reported that $\mathrm{La}, \mathrm{Ce}$, and $\mathrm{Nd}$ accumulated in the nuclei and mitochondria of mice hepatocyte and induced oxidative damages. As a result, given the large proportion of $\mathrm{Y}$ accumulated in cellular debris for $C$. riparius at the end of our bioassays, we must assume that $\mathrm{Y}$ bound to this fraction likely contributes to its toxicological effects on this organism.

Note that the $C$. riparius debris fraction likely included its exoskeleton and the associated Y. To reduce the contribution of $\mathrm{Y}$ from this tissue to $\mathrm{Y}$ in the debris in future studies, the heavily chitinised head capsule of $C$. riparius could be removed before subcellular fractionation.

The significant accumulation of $\mathrm{Y}$ in the mitochondrial fraction of $C$. riparius at our maximal exposure level relative to lower exposure levels (Figure 2) is consistent with the "spillover hypothesis" observed by many authors for other metals. ${ }^{19}$ Thus, the cell capacity to detoxify Y by accumulation in the $\mathrm{NaOH}$-resistant fraction would be exceeded at our maximal exposure level, leading to a spillover of $\mathrm{Y}$ in mitochondrial membranes, an MSF.

Oncorhynchus mykiss. Liver cells were targeted for fractionation in $O$. mykiss because yttrium from water would first enter through the gills, reach the kidney, and eventually the liver, which is usually considered an important site of detoxification. Yttrium in O. mykiss liver cells was mainly present in mitochondrial membranes; this fraction represented between 34 and $39 \%$ of the total accumulated Y (Figure 3) and reached a maximal concentration of $4.0 \pm 0.4 \mathrm{mg} \mathrm{Y} \mathrm{kg} \mathrm{dw}$ of the fraction (Supporting Information, Table S7). The remaining bioaccumulated Y was divided between the HDP and the microsomes fractions. They contained from 19 to $26 \%$ of $\mathrm{Y}$ each and accumulated statistically identical amounts of Y. Unlike D. magna and C. riparius, in O. mykiss liver, MDF represented less than $15 \%$ of the total amount of bioaccumulated Y. Also, there were no significant differences between the amounts of $\mathrm{Y}$ bioaccumulated in the $\mathrm{NaOH}$ resistant and the HSP fractions (Figure 3).

Several authors studied metal distribution inside fish liver cells. For instance, from 37 to $48 \%$ and from 20 to $30 \%$ of $\mathrm{Cu}$ was accumulated in the organelles (mitochondria + lysosomes/ microsomes) of $O$. mykiss liver cells ${ }^{60}$ and Cyprinus carpio liver cells ${ }^{61}$ respectively, in previous studies. Thus, as well as $\mathrm{Y}$, the organelles appear as the first putative MSF that accumulated $\mathrm{Cu}$ in O. mykiss liver. ${ }^{60,61}$ In addition, the low percentage of $\mathrm{Y}$ accumulated in MDF fraction was also observed for $\mathrm{Hg}$ in

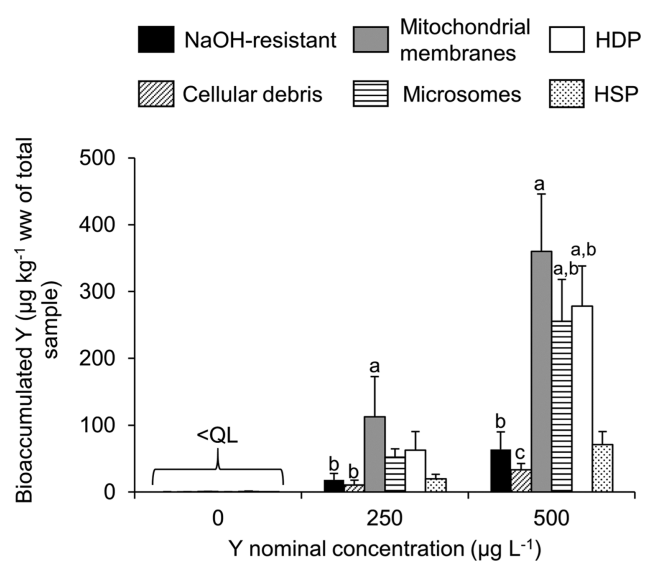

Figure 3. Bioaccumulation of $Y$ in each validated fraction of $O$. mykiss liver (mean $\pm \mathrm{SD}$ in $\mu \mathrm{g}$ of $\mathrm{Y}$ in the fraction per kilogram of the total wet weight of the sample, $n=3$ ) as a function of exposure concentration. Different letters indicate a significant difference of $Y$ accumulation among fractions for a given $\mathrm{Y}$ exposure level (ANOVA; $F(5,12)=5.7$ and 21 for exposure at 250 and $500 \mu \mathrm{g} \mathrm{L}{ }^{-1}$, respectively; followed by Tukey's pairwise comparison test, $p<0.05$ ). The absence of a letter indicates that there is no significant difference. QL: $8 \mathrm{ng}$ $\mathrm{L}^{-1}$.

Salvelinus alpinus liver, ${ }^{62}$ and less than $15 \%$ of the accumulated $\mathrm{Hg}$ was in the MDF. However, in S. alpinus liver, $\mathrm{Hg}$ tended to accumulate more in the HDP than in the organelles fraction. ${ }^{62}$ Moreover, at least $30 \%$ of $\mathrm{Cd}$ inside the liver cells of $O$. mykiss $^{60}$ and Perca flavescens ${ }^{63}$ was found in MDF, suggesting an effective subcellular detoxication strategy for these metals in contrast to Y.

Comparison of $\mathrm{Y}$ Subcellular Detoxication between Species. For both invertebrates, considering the MDF, Y was mostly found in the $\mathrm{NaOH}$-resistant fraction. HSP was the second fraction which is also included in the MDF and represented less than $10 \%$ of total $\mathrm{Y}$ in all our organisms (Figure 4). Hence, $\mathrm{Y}$ binding to granules is likely the main route of Y detoxification in cells. Racine (2016) also reached this conclusion for REE subcellular fractionation in an alga, Chlamydomonas reinhardtii. ${ }^{64}$ However, further investigations to confirm this assumption will be required in invertebrates. Also, it could be interesting to extend the analyses to evaluate

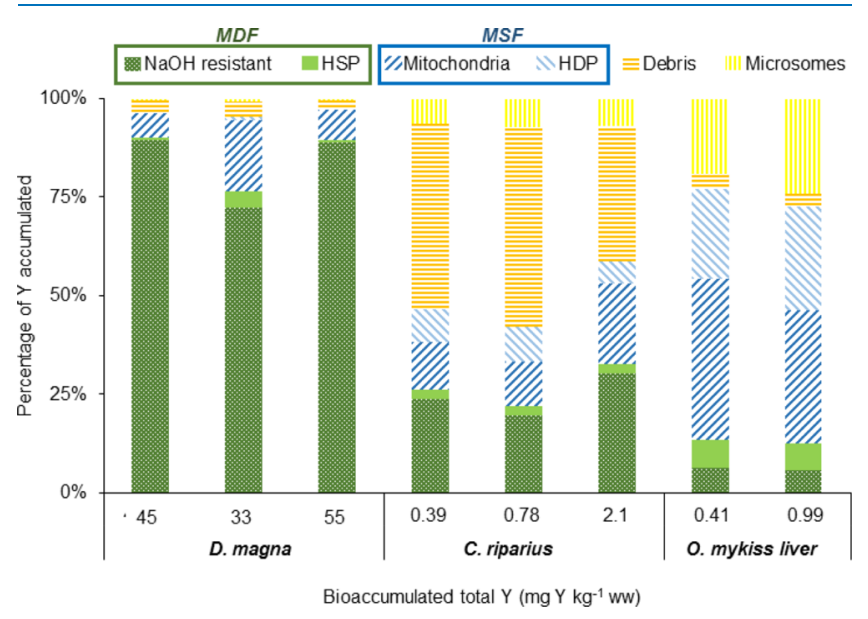

Figure 4. Percentage of $\mathrm{Y}$ recovered in each fraction as a function of the amount of bioaccumulated total $\mathrm{Y}$ in each organism: MDF, MSF, HSP, and HDP. 
which type of granules is involved in the $\mathrm{Y}$ detoxification. Indeed, Hopkin ${ }^{65}$ defined four types of granules depending on the ligands that compose them. Considering the $\mathrm{Y}$ ability to be bound with calcium-binding proteins, ${ }^{66}$ we hypothesize that $\mathrm{Y}$ rich granules are most likely constituted of calcium carbonate. Note that Hopkin ${ }^{65}$ considered that this type of granules is unlikely to be used for metal detoxification but as resoluble temporary stores of calcium.

Among the MSF, Y was mostly found in mitochondria in all our organisms (Figure 4). The interaction of $\mathrm{Y}$ with mitochondrial functions could thus, at least partly, explain the toxic effects of $\mathrm{Y}$ in our organisms. Gao et al. ${ }^{67}$ suggested that a way for $\mathrm{Eu}^{3+}$ and $\mathrm{La}^{3+}$ to accumulate inside plant cells was to bind to membranes of mitochondria, chloroplasts, and cytoplasts via $\mathrm{Ca}^{2+}$ channels. Besides, several authors have measured adverse effects which can be linked to accumulation in mitochondria. For instance, oxidative damages on mitochondria of mice hepatocytes following an exposure to La, Ce, and $\mathrm{Nd}$ were observed. ${ }^{59}$ Moreover, a decrease of the $\mathrm{Ca}^{2+}$-dependent basal respiration rate in rat heart mitochondria following an exposure to $\mathrm{Y}$ was also observed. ${ }^{68}$

This study represents a first attempt to compare an REE subcellular handling between different organisms at exposure levels with measured adverse effects. It emphasizes the importance of the $\mathrm{NaOH}$ fraction and mitochondrial membrane in understanding $\mathrm{Y}$ detoxification and toxicity mechanisms. It also underlines species-specific $\mathrm{Y}$ subcellular management like D. magna capacity to accumulate much higher proportion of $\mathrm{Y}$ in its MDF than $C$. riparius and $O$. mykiss. This study contributes to improve our knowledge about REE risk assessment and provides first insights into their subcellular handling.

\section{MATERIALS AND METHODS}

Toxicity Bioassays. D. magna and C. riparius were cultured in house at the Centre d'expertise en analyse environnementale du Québec (CEAEQ, Quebec City, QC, Canada). O. mykiss individuals were purchased from the Pisciculture des Arpents Verts (Sainte-Edwidge, QC, Canada) and acclimated to laboratory conditions for at least 3 weeks prior to use. A solution prepared with a Y standard $(10000 \mu \mathrm{g} / \mathrm{mL} \mathrm{Y} \mathrm{in} 3 \%$ $\mathrm{HNO}_{3}$, TraceCERT, FLUKA) was used to spike the water and the sediment. The exposure range for each bioassay was not chosen to approximate the environmental concentrations reported to date for $\mathrm{Y}$ but to include concentrations with and without observed effects.

Unless otherwise mentioned, all exposure concentrations were determined as described in the section "Yttrium Measurements and Quality Control”. Detailed descriptions of each bioassay are given in the Supporting Information. Also, monitoring of $\mathrm{Y}$ dissolved in the exposure media are presented in Tables S3-S5, respectively, for D. magna, C. riparius, and $O$. mykiss and $\mathrm{Y}$ speciation at the beginning of each test is presented in the Supporting Information, Table S6. Briefly, the initial exposure solution $\mathrm{pH}$ and hardness comprised between 7.4-7.9 and 45-130 mg L ${ }^{-1}$ of $\mathrm{CaCO}_{3}$. No organic ligands were added and, in these conditions, $\mathrm{Y}$ was mainly present in the form of $\mathrm{YCO}_{3}{ }^{+}(61-80 \%)$ and $\mathrm{Y}\left(\mathrm{CO}_{3}\right)_{2}^{-}(8-36 \%)$.

Daphnia magna. A 7-day D. magna growth test was performed in semistatic conditions (water renewed daily) at a hardness of $130 \mathrm{mg} \mathrm{L}^{-1}$ of $\mathrm{CaCO}_{3}$ and a $\mathrm{pH}$ of 7.9. The reconstituted water and the adjustment of its hardness were made according to USEPA protocols ${ }^{21}$ (Supporting Informa- tion, Table S1). D. magna neonates $(<24 \mathrm{~h})$ were exposed individually (one individual per experimental unit, 10 experimental unit per treatment) in reconstituted water at five nominal Y concentrations $(0,200,400,800$, and $1200 \mu \mathrm{g}$ $\left.\mathrm{L}^{-1}\right)$ with 10 replicates per treatment. Additional experiments at 66 and $90 \mathrm{mg} \mathrm{CaCO} \mathrm{L}^{-1}$ were also performed.

Chironomus riparius. A 10-day sediment growth test with a sediment collected from Lac Croche at the Station de biologie des Laurentides (QC, Canada), spiked with Y (52, 144, and $450 \mathrm{mg} \mathrm{kg}^{-1}$ dry weight, $\mathrm{dw}$ ), was carried out with C. riparius as described elsewhere. ${ }^{22}$ C. riparius were exposed by groups of 30 individuals with 3 replicates per treatment. Hardness and $\mathrm{pH}$ in the water medium were set at $45 \mathrm{mg} \mathrm{L}^{-1}$ of $\mathrm{CaCO}_{3}$ and 7.5 , respectively. Details of the preparation of the Y-spiked sediment and of the characteristics of the natural sediment are given in the Supporting Information.

Oncorhynchus mykiss. A 28-day growth test with five $\mathrm{Y}$ concentrations $\left(0,250,500,1000\right.$, and $\left.2000 \mu \mathrm{g} \mathrm{L}^{-1}\right)$ was conducted with $O$. mykiss according to the international standard ISO $10229^{23}$ with some modifications. For each concentration tested, 10 individuals of $O$. mykiss were exposed in $20 \mathrm{~L}$ of Y-spiked reconstituted water (Supporting Information, Table S1), in semistatic conditions, $80 \%$ of the test water being renewed every $48 \mathrm{~h}$. The water hardness was set at $45 \mathrm{mg} \mathrm{L}^{-1}$ of $\mathrm{CaCO}_{3}$ and $\mathrm{pH}$ at 7.7. Trout were fed twice daily at a rate of $2 \%$ of body weight per day with a commercial feed (see the Supporting Information for details). Fish consumed all the food provided in less than $1 \mathrm{~min}$ during our experiments, so it is unlikely that dietary uptake was significant. Further, we measured $\mathrm{Y}$ in the food before exposure and it contained low concentrations of $\mathrm{Y}$ that were not comparable with the high concentration of $\mathrm{Y}$ administered through aqueous exposure.

Subcellular Fractionation Protocol. Each organism was rinsed with a $1 \mathrm{mM}$ EDTA solution to remove the $\mathrm{Y}$ adsorbed to the surface of its body before sampling for subcellular fractionation. Samples of each organism were partitioned into six subcellular fractions with the fractionation protocol developed by Wallace et al. customized for our three species. ${ }^{15,16}$ Figure S1 in the Supporting Information presents the fractionation protocol with the customization applied for each species. In a previous publication, we validated the location of mitochondria (membrane and matrix), lysosomes, and cytosol between fractions (Supporting Information, Figure S1) by performing enzymatic biomarker assays on the separated fractions. ${ }^{16}$ Thus, a distinction is made between these validated fractions and those predicted from the literature for which, to our knowledge, no relevant method of validation has been developed so far. These predicted fractions are the cellular debris (e.g., nuclei and membranes), the $\mathrm{NaOH}$-resistant fraction, microsomes, the HDP, and the HSP.

Briefly, for each organism, 60-100 mg of tissue (whole organism: D. magna, C. riparius; liver: O. mykiss) was sampled and suspended in Tris- $\mathrm{HCl}(25 \mathrm{mM}$; OmniPur) and sucrose buffer (250 mM; pH 7.4; Sigma-Aldrich) at a final ratio of 1:8 (weight $[\mathrm{mg}]$ : buffer volume $[\mu \mathrm{L}]$ ). Samples were homogenized on a motorized Potter-Elvehjem homogenizer equipped with a Teflon pestle at $570 \mathrm{rpm}$ (Fisher Scientific) and, except for $C$. riparius, were sonicated $(22 \mathrm{~W}, 20 \%)$ (Branson 250, with a $4.8 \mathrm{~mm}$ diameter microtip probe) over a second homogenization step. After each homogenization, an aliquot of $40 \mu \mathrm{L}$ was collected for estimating the total Y burden of the 
sample and the rest was centrifuged at $800-1500 \mathrm{~g}$ for $15 \mathrm{~min}$ at $4{ }^{\circ} \mathrm{C}$ to separate the debris fraction from the other fractions (Supporting Information, Figure S1). The resulting supernatant was collected and subjected to a second centrifugation step at $15000-25000 \mathrm{~g}$ for $30 \mathrm{~min}$ at $4{ }^{\circ} \mathrm{C}$ (Supporting Information, Figure S1). The mitochondrial pellet was then isolated, and an ultracentrifugation step was performed on the remaining supernatant at $100000-190000 \mathrm{~g}$ for $60 \mathrm{~min}$ at 4 ${ }^{\circ} \mathrm{C}$. The pellet was separated from the supernatant at this step (Supporting Information, Figure S1). This supernatant was heated at $80{ }^{\circ} \mathrm{C}$ for $10 \mathrm{~min}$, cooled for $1 \mathrm{~h}$ at $4{ }^{\circ} \mathrm{C}$, and finally centrifuged at $50000 \mathrm{~g}$ for $10 \mathrm{~min}$ at $4{ }^{\circ} \mathrm{C}$ to separate the HSP from the HDP. To separate cellular debris from the $\mathrm{NaOH}$ resistant fraction, the debris fraction was filled with $500 \mu \mathrm{L}$ of Milli-Q water and vortexed. The mixture was heated at $95{ }^{\circ} \mathrm{C}$ for $2 \mathrm{~min}$, then $500 \mu \mathrm{L}$ of $\mathrm{NaOH} 1 \mathrm{~N}$ (99.998\%, SigmaAldrich) was added, and the temperature was set at $80{ }^{\circ} \mathrm{C}$ for 1 h. Finally, the suspension was centrifuged at $10000 \mathrm{~g}$ for 10 min at $20{ }^{\circ} \mathrm{C}$ (Supporting Information, Figure S1).

Because of the presence of a cuticular exoskeleton, arthropods were more difficult to be homogenized and fractionated than $O$. mykiss liver. The accumulation of $\mathrm{Y}$ in the debris fraction, which likely collects this exoskeleton and can be a significant site of metal accumulation, must therefore be considered with caution.

Yttrium Measurements and Quality Control. To minimize $\mathrm{Y}$ accidental contamination, all labware was soaked in $\mathrm{HNO}_{3}(15 \%, \mathrm{v} / \mathrm{v}$, Optima grade, Fisher Scientific) and rinsed seven times in Milli-Q water before use.

Centrifuged pellet fractions resulting from the subcellular partitioning ( $\mathrm{NaOH}$-resistant fraction, mitochondrial membranes, microsomes, and HDP), aliquots sampled as homogenate, and O. mykiss remaining parts were freeze-dried for $24 \mathrm{~h}$, weighed, and stored at $-80{ }^{\circ} \mathrm{C}$. The freeze-dried fractions and the two other ones (debris and HSP) were digested at $65{ }^{\circ} \mathrm{C}$ in $500 \mu \mathrm{L}$ of $\mathrm{HNO}_{3}(70 \%, \mathrm{v} / \mathrm{v})$, whereas $O$. mykiss body remaining parts, representing heavier mass, were subjected to the same procedure but in $4 \mathrm{~mL}$ of $\mathrm{HNO}_{3}$. Then, 9.5 and $45 \mathrm{~mL}$ of Milli-Q water were added in the digestates of subcellular fractions and body remaining parts, respectively.

Concentrations of $\mathrm{Y}$ in subcellular fractions, homogenates, water, and sediments were measured with an inductively coupled plasma-mass spectrometer (Thermo Elemental X Series). To ensure the quality of these measurements, samples of similar weight of a certified standard reference material, BCR 668 (mussel tissue, Institute for Reference Materials and Measurements), underwent the same digestion procedure and analysis. Mean $[ \pm$ standard deviation $(\mathrm{SD})]$ recoveries of BCR 668 reference sample $(n=9)$ were within the certified range for $\mathrm{Y}(103 \pm 10 \%)$. For sediments, the method detection limit was $2 \mathrm{ng} \mathrm{kg}^{-1}$, and for water, it was $3 \mathrm{ng} \mathrm{L}^{-1}$. The homogenate $(40 \mu \mathrm{L})$ sampled over the fractionation procedure was analyzed to confirm metal recovery following subcellular fractionation. Recoveries were expressed as the ratio of the sum of the $\mathrm{Y}$ burden in the six fractions divided by the total sample Y burden assessed from the $40 \mu \mathrm{L}$ of the homogenate, multiplied by 100 . The mean $( \pm S D)$ recovery values of $Y$ were $90 \pm 11 \%(n=12)$ for D. magna, $70.0 \pm 0.1 \%(n=12)$ for $C$. riparius, and $87 \pm 22 \%(n=9)$ for $O$. mykiss. Note that it was assumed by Cardon et al. ${ }^{16}$ that around $25 \%$ of C. riparius samples were probably not efficiently homogenized with the subcellular fractionation procedure performed on this species.
It could explain why we obtained lower recovery values for $C$. riparius.

Calculation and Statistical Analysis. To assess the effect of $\mathrm{Y}$ on growth, the relative size of animals was calculated as the size of the organism for a given $\mathrm{Y}$ exposure level divided by the mean size of the controls.

Yttrium concentrations in every subcellular fraction were expressed as the $\mathrm{Y}$ burden in the fraction divided by the total sample wet weight ( $w w)\left(\mathrm{mg} \mathrm{kg}^{-1} \mathrm{ww}\right)$. The yttrium burden in a given fraction was divided by the sum of $\mathrm{Y}$ burden in all fractions and multiplied by 100 to assess the relative contribution of each subcellular fraction to the total Y burden in terms of percentages (\%).

Data are expressed as means \pm coefficient of variation $(\mathrm{CV})$ for $\mathrm{Y}$ total bioaccumulation and relative organism size, and as mean $\pm S D$ for $Y$ exposure measurements and $Y$ bioaccumulation in fractions. Significant differences of organism size at the end of the bioassays or of Y burden in a given fraction/organism between $\mathrm{Y}$ exposure levels were tested with analysis of variance (ANOVA), followed by Tukey's pairwise comparison test $(p<0.05)$. The assumptions of normality and homoscedasticity were verified by ShapiroWilk's and Levene's tests, respectively. Statistical analyses were performed using $\mathrm{R}$ software version 3.4.4.

\section{ASSOCIATED CONTENT}

\section{S Supporting Information}

The Supporting Information is available free of charge on the ACS Publications website at DOI: 10.1021/acsomega.9b01238.

Methods on bioassays, exposure media, and subcellular fractionation; results on bioassay exposure monitoring and bioassay toxicity results; subcellular fractionation in Daphnia after $24 \mathrm{~h}$; and yttrium concentrations by subcellular fractions (PDF)

\section{AUTHOR INFORMATION}

\section{Corresponding Author}

*E-mail: m.amyot@umontreal.ca. Phone 1-514-343-7496 (M.A.).

ORCID $\odot$

Claude Fortin: 0000-0002-2479-1869

Marc Amyot: 0000-0002-0340-3249

\section{Funding}

This research was funded through the Natural Sciences and Engineering Research Council (NSERC) Discovery grant and an NSERC strategic grant (TRIVALENCE) to M. Amyot. This work was supported by the NSERC CREATE Mine of Knowledge network through a scholarship to P.-Y.C. M.A. and C.F. were supported by the Canada Research Chair Program. All experiments were performed at the CEAEQ with labware purchased and provided by MELCC.

\section{Notes}

The authors declare no competing financial interest.

\section{ACKNOWLEDGMENTS}

The authors would like to thank the Centre d'expertise en analyse environnementale du Québec (Ministère de l'Environnement et de la Lutte contre les changements climatiques (MELCC) for their technical assistance in the breeding of organisms and chemical analyses. They also thank the 
technicians of the M.A. laboratory and INRS-ETE for the laboratory assistance and their help in the analysis of rare earth elements.

\section{REFERENCES}

(1) Alonso, E.; Sherman, A. M.; Wallington, T. J.; Everson, M. P.; Field, F. R.; Roth, R.; Kirchain, R. E. Evaluating Rare Earth Element Availability: A Case with Revolutionary Demand from Clean Technologies. Environ. Sci. Technol. 2012, 46, 3406-3414.

(2) Massari, S.; Ruberti, M. Rare Earth Elements as Critical Raw Materials: Focus on International Markets and Future Strategies. Resour. Policy 2013, 38, 36-43.

(3) Gwenzi, W.; Mangori, L.; Danha, C.; Chaukura, N.; Dunjana, N.; Sanganyado, E. Sources, Behaviour, and Environmental and Human Health Risks of High-Technology Rare Earth Elements as Emerging Contaminants. Sci. Total Environ. 2018, 636, 299-313.

(4) Kulaksiz, S.; Bau, M. Rare Earth Elements in the Rhine River, Germany: First Case of Anthropogenic Lanthanum as a Dissolved Microcontaminant in the Hydrosphere. Environ. Int. 2011, 37, 973979.

(5) Atibu, E. K.; Devarajan, N.; Laffite, A.; Giuliani, G.; Salumu, J. A.; Muteb, R. C.; Mulaji, C. K.; Otamonga, J.-P.; Elongo, V.; Mpiana, P. T.; et al. Assessment of trace metal and rare earth elements contamination in rivers around abandoned and active mine areas. The case of Lubumbashi River and Tshamilemba Canal, Katanga, Democratic Republic of the Congo. Geochemistry 2016, 76, 353-362.

(6) Sneller, F. E.; Kalf, D.; Weltje, L.; Van Wezel, A. Maximum Permissible Concentrations and Negligible Concentrations for Rare Earth Elements (REEs). RIVM Report, 2000; Vol. 601, p 66.

(7) Babula, P.; Adam, V.; Opatrilova, R.; Zehnalek, J.; Havel, L.; Kizek, R. Uncommon heavy metals, metalloids and their plant toxicity: a review. Organic Farming, Pest Control and Remediation of Soil Pollutants; Springer: Dordrecht, 2009; pp 275-317.

(8) Liu, X.; Byrne, R. H. Rare earth and yttrium phosphate solubilities in aqueous solution. Geochim. Cosmochim. Acta 1997, 61, $1625-1633$.

(9) Weltje, L.; Heidenreich, H.; Zhu, W.; Wolterbeek, H. T.; Korhammer, S.; de Goeij, J. J. M.; Markert, B. Lanthanide Concentrations in Freshwater Plants and Molluscs, Related to Those in Surface Water, Pore Water and Sediment. A Case Study in The Netherlands. Sci. Total Environ. 2002, 286, 191-214.

(10) Ng, T.; Smith, S. Review of aquatic effects of lanthanides and other uncommon elements. EC Contribution Agreement with the CNTC for 2010/2011, 2011.

(11) Borgmann, U.; Couillard, Y.; Doyle, P.; Dixon, D. G. Toxicity of Sixty-Three Metals and Metalloids to Hyalella Azteca at Two Levels of Water Hardness. Environ. Toxicol. Chem. 2005, 24, 641-652.

(12) Cui, J.; Zhang, Z.; Bai, W.; Zhang, L.; He, X.; Ma, Y.; Liu, Y.; Chai, Z. Effects of Rare Earth Elements $\mathrm{La}$ and $\mathrm{Yb}$ on the Morphological and Functional Development of Zebrafish Embryos. J. Environ. Sci. 2012, 24, 209-213.

(13) Ding, Y.; Tian, Y.; Zeng, Z.; Shuai, P.; Lan, H.; Zhu, X.; Zhong, $\mathrm{Y}$.; Wu, L.; Fan, $\mathrm{X} . \mathrm{YCl}_{3}$ promotes neuronal cell death by inducing apoptotic pathways in rats. BioMed Res. Int. 2017, 2017, 2183658.

(14) Pan, K.; Wang, W.-X. Biodynamics to Explain the Difference of Copper Body Concentrations in Five Marine Bivalve Species. Environ. Sci. Technol. 2009, 43, 2137-2143.

(15) Wallace, W.; Lee, B.; Luoma, S. Subcellular Compartmentalization of $\mathrm{Cd}$ and $\mathrm{Zn}$ in Two Bivalves. I. Significance of Metal-Sensitive Fractions (MSF) and Biologically Detoxified Metal (BDM). Mar. Ecol. Prog. Ser. 2003, 249, 183-197.

(16) Cardon, P.-Y.; Caron, A.; Rosabal, M.; Fortin, C.; Amyot, M. Enzymatic Validation of Species-Specific Protocols for Metal Subcellular Fractionation in Freshwater Animals. Limnol Oceanogr. Methods 2018, 16, 537-555.

(17) Wang, M.-J.; Wang, W.-X. Cadmium in Three Marine Phytoplankton: Accumulation, Subcellular Fate and Thiol Induction. Aquat. Toxicol. 2009, 95, 99-107.
(18) Campana, O.; Taylor, A. M.; Blasco, J.; Maher, W. A.; Simpson, S. L. Importance of Subcellular Metal Partitioning and Kinetics to Predicting Sublethal Effects of Copper in Two Deposit-Feeding Organisms. Environ. Sci. Technol. 2015, 49, 1806-1814.

(19) Cooper, S.; Bonneris, E.; Michaud, A.; Pinel-Alloul, B.; Campbell, P. G. C. Influence of a Step-Change in Metal Exposure $(\mathrm{Cd}, \mathrm{Cu}, \mathrm{Zn})$ on Metal Accumulation and Subcellular Partitioning in a Freshwater Bivalve, Pyganodon grandis: A Long-Term Transplantation Experiment between Lakes with Contrasting Ambient Metal Levels. Aquat. Toxicol. 2013, 132-133, 73-83.

(20) Rainbow, P. S.; Liu, F.; Wang, W.-X. Metal Accumulation and Toxicity: The Critical Accumulated Concentration of Metabolically Available Zinc in an Oyster Model. Aquat. Toxicol. 2015, 162, 102108.

(21) United States Environmental Protection Agency. Short-Term Methods for Estimating the Chronic Toxicity of Effluents and Receiving Waters to Freshwater Organisms, 4th ed., Oct 2002, No. October, 1350.

(22) Environnement Canada. Biological Test Method: Test for Survival and Growth in Sediment Using Larvae of Freshwater Midges (Chironomus tentans or Chironomus riparius), 1997.

(23) ISO 10229. Water Quality-Determination of the Prolonged Toxicity of Substances to Freshwater Fish-Method for Evaluating the Effects of Substances on the Growth Rate of Rainbow Trout (Oncorhynchus mykiss Walbaum), Cei, 1994.

(24) Vukov, O.; Smith, D. S.; McGeer, J. C. Acute Dysprosium Toxicity to Daphnia pulex and Hyalella azteca and Development of the Biotic Ligand Approach. Aquat. Toxicol. 2016, 170, 142-151.

(25) Barry, M. J.; Meehan, B. J. The Acute and Chronic Toxicity of Lanthanum to Daphnia carinata. Chemosphere 2000, 41, 1669-1674.

(26) Ma, Y.; Wang, J.; Peng, C.; Ding, Y.; He, X.; Zhang, P.; Li, N.; Lan, T.; Wang, D.; Zhang, Z.; et al. Toxicity of Cerium and Thorium on Daphnia magna. Ecotoxicol. Environ. Saf. 2016, 134, 226-232.

(27) González, V.; Vignati, D. A. L.; Pons, M.-N.; MontargesPelletier, E.; Bojic, C.; Giamberini, L. Lanthanide Ecotoxicity: First Attempt to Measure Environmental Risk for Aquatic Organisms. Environ. Pollut. 2015, 199, 139-147.

(28) Amyot, M.; Clayden, M. G.; Macmillan, G. A.; Perron, T.; Arscott-Gauvin, A. Fate and Trophic Transfer of Rare Earth Elements in Temperate Lake Food Webs. Environ. Sci. Technol. 2017, 51, 6009-6017.

(29) Yang, X.; Yin, D.; Sun, H.; Wang, X.; Dai, L.; Chen, Y.; Cao, M. Distribution and Bioavailability of Rare Earth Elements in Aquatic Microcosm. Chemosphere 1999, 39, 2443-2450.

(30) MacMillan, G. A.; Chételat, J.; Heath, J. P.; Mickpegak, R.; Amyot, M. Rare Earth Elements in Freshwater, Marine, and Terrestrial Ecosystems in the Eastern Canadian Arctic. Environ. Sci.: Processes Impacts 2017, 19, 1336-1345.

(31) Herrmann, H.; Nolde, J.; Berger, S.; Heise, S. Aquatic ecotoxicity of lanthanum - A review and an attempt to derive water and sediment quality criteria. Ecotoxicol. Environ. Saf. 2016, 124, 213238.

(32) Romero-Freire, A.; Minguez, L.; Pelletier, M.; Cayer, A.; Caillet, C.; Devin, S.; Gross, E. M.; Guérold, F.; Pain-Devin, S.; Vignati, D. A. L.; et al. Assessment of Baseline Ecotoxicity of Sediments from a Prospective Mining Area Enriched in Light Rare Earth Elements. Sci. Total Environ. 2018, 612, 831-839.

(33) Schaller, J. Invertebrate Shredder as a Factor Controlling the Fixation Potential for Metals/Metalloids in Organic Matter during Decay. Ecol. Eng. 2013, 53, 200-204.

(34) Ricciardi, A.; Bourget, E. Weight-to-Weight Conversion Factors for Marine Benthic Macroinvertebrates. Mar. Ecol. Prog. Ser. 1998, $171,245-251$.

(35) UNIT, Aquatic Toxicology. PhoslockTM Toxicity Testing with Three Sediment Dwelling Organisms (Hyalella azteca, Hexagenia spp. and Chironomus dilutus) and Two Water Column Dwelling Organisms (Rainbow Trout and Daphnia magna), 2009. 
(36) Stauber, J. Toxicity Testing of Modified Clay Leachates Using Freshwater Organisms; CSIRO Center for Advanced Analytical Chemistry Energy Technology, 2000, report No: ET/IR267R.

(37) Mayfield, D. B.; Fairbrother, A. Examination of rare earth element concentration patterns in freshwater fish tissues. Chemosphere 2015, 120, 68-74.

(38) Yang, L.; Wang, X.; Nie, H.; Shao, L.; Wang, G.; Liu, Y. Residual Levels of Rare Earth Elements in Freshwater and Marine Fish and Their Health Risk Assessment from Shandong, China. Mar. Pollut. Bull. 2016, 107, 393-397.

(39) Lapointe, D.; Gentès, S.; Ponton, D. E.; Hare, L.; Couture, P. Influence of Prey Type on Nickel and Thallium Assimilation, Subcellular Distribution and Effects in Juvenile Fathead Minnows (Pimephales promelas). Environ. Sci. Technol. 2009, 43, 8665-8670.

(40) Wang, W. X.; Guan, R. Subcellular distribution of zinc in Daphnia magna and implication for toxicity. Environ Toxicol Chem 2010, 29, 1841-1848.

(41) Frelon, S.; Mounicou, S.; Lobinski, R.; Gilbin, R.; Simon, O. Subcellular fractionation and chemical speciation of uranium to elucidate its fate in gills and hepatopancreas of crayfish Procambarus clarkii. Chemosphere 2013, 91, 481-490.

(42) Geffard, A.; Sartelet, H.; Garric, J.; Biagianti-Risbourg, S.; Delahaut, L.; Geffard, O. Subcellular Compartmentalization of Cadmium, Nickel, and Lead in Gammarus fossarum: Comparison of Methods. Chemosphere 2010, 78, 822-829.

(43) Rainbow, P. S.; Amiard, J. C.; Amiard-Triquet, C.; Cheung, M. S.; Zhang, L.; Zhong, H.; Wang, W.-X. Trophic Transfer of Trace Metals: Subcellular Compartmentalization in Bivalve Prey, Assimilation by a Gastropod Predator and in Vitro Digestion Simulations. Mar. Ecol. Prog. Ser. 2007, 348, 125-138.

(44) Dang, F.; Rainbow, P. S.; Wang, W.-X. Dietary Toxicity of Field-Contaminated Invertebrates to Marine Fish: Effects of Metal Doses and Subcellular Metal Distribution. Aquat. Toxicol. 2012, 120121, 1-10.

(45) Sánchez-Marín, P.; Beiras, R. Subcellular Distribution and Trophic Transfer of $\mathrm{Pb}$ from Bivalves to the Common Prawn Palaemon serratus. Ecotoxicol. Environ. Saf. 2017, 138, 253-259.

(46) Yu, R.-Q.; Wang, W.-X. Trace metal assimilation and release budget in Daphnia magna. Limnol. Oceanogr. 2002, 47, 495-504.

(47) Greenaway, P. Calcium Balance and Moulting in the Crustacea. Biol. Rev. 1985, 60, 425-454.

(48) Pillai, C. K. S.; Paul, W.; Sharma, C. P. Chitin and Chitosan Polymers: Chemistry, Solubility and Fiber Formation. Prog. Polym. Sci. 2009, 34, 641-678.

(49) Beedle, A. M.; Hamid, J.; Zamponi, G. W. Inhibition of Transiently Expressed Low- and High-Voltage-Activated Calcium Channels by Trivalent Metal Cations. J. Membr. Biol. 2002, 187, 225238.

(50) Bosco-Santos, A.; Luiz-Silva, W.; Silva-Filho, E. V. d.; Souza, M. D. C. d.; Dantas, E. L.; Navarro, M. S. Fractionation of rare earth and other trace elements in crabs, Ucides cordatus, from a subtropical mangrove affected by fertilizer industry. J. Environ. Sci. 2017, 54, 6976.

(51) Rosabal, M.; Hare, L.; Campbell, P. G. C. Subcellular Metal Partitioning in Larvae of the Insect Chaoborus Collected along an Environmental Metal Exposure Gradient (Cd, Cu, Ni and $\mathrm{Zn})$. Aquat. Toxicol. 2012, 120-121, 67-78.

(52) Dumas, J.; Hare, L. The Internal Distribution of Nickel and Thallium in Two Freshwater Invertebrates and Its Relevance to Trophic Transfer. Environ. Sci. Technol. 2008, 42, 5144-5149.

(53) Dubois, M.; Hare, L. Selenium Assimilation and Loss by an Insect Predator and Its Relationship to Se Subcellular Partitioning in Two Prey Types. Environ. Pollut. 2009, 157, 772-777.

(54) Dubois, M.; Hare, L. Subcellular Distribution of Cadmium in Two Aquatic Invertebrates: Change over Time and Relationship to $\mathrm{Cd}$ Assimilation and Loss by a Predatory Insect. Environ. Sci. Technol. 2009, 43, 356-361.

(55) Gimbert, F.; Geffard, A.; Guédron, S.; Dominik, J.; Ferrari, B. J. D. Mercury Tissue Residue Approach in Chironomus riparius:
Involvement of Toxicokinetics and Comparison of Subcellular Fractionation Methods. Aquat. Toxicol. 2016, 171, 1-8.

(56) Campbell, P. G. C.; Giguère, A.; Bonneris, E.; Hare, L. Cadmium-handling strategies in two chronically exposed indigenous freshwater organisms-the yellow perch (Perca flavescens) and the floater mollusc (Pyganodon grandis). Aquat. Toxicol. 2005, 72, 8397.

(57) Casado-Martinez, M. C.; Duncan, E.; Smith, B. D.; Maher, W. A.; Rainbow, P. S. Arsenic Toxicity in a Sediment-Dwelling Polychaete: Detoxification and Arsenic Metabolism. Ecotoxicology 2012, 21, 576-590.

(58) Fusconi, A.; Repetto, O.; Bona, E.; Massa, N.; Gallo, C.; Dumas-Gaudot, E.; Berta, G. Effects of Cadmium on Meristem Activity and Nucleus Ploidy in Roots of Pisum sativum L. Cv. Frisson Seedlings. Environ. Exp. Bot. 2006, 58, 253-260.

(59) Huang, P.; Li, J.; Zhang, S.; Chen, C.; Han, Y.; Liu, N.; Xiao, Y.; Wang, H.; Zhang, M.; Yu, Q.; et al. Effects of Lanthanum, Cerium, and Neodymium on the Nuclei and Mitochondria of Hepatocytes: Accumulation and Oxidative Damage. Environ. Toxicol. Pharmacol. 2011, 31, 25-32.

(60) Kamunde, C.; MacPhail, R. Bioaccumulation and Hepatic Speciation of Copper in Rainbow Trout (Oncorhynchus mykiss) during Chronic Waterborne Copper Exposure. Arch. Environ. Contam. Toxicol. 2008, 54, 493-503.

(61) Eyckmans, M.; Blust, R.; De Boeck, G. Subcellular Differences in Handling $\mathrm{Cu}$ Excess in Three Freshwater Fish Species Contributes Greatly to Their Differences in Sensitivity to Cu. Aquat. Toxicol. 2012, 118-119, 97-107.

(62) Barst, B. D.; Rosabal, M.; Campbell, P. G. C.; Muir, D. G. C.; Wang, X.; Köck, G.; Drevnick, P. E. Subcellular distribution of trace elements and liver histology of landlocked Arctic char (Salvelinus alpinus) sampled along a mercury contamination gradient. Environ. Pollut. 2016, 212, 574-583.

(63) Giguere, A.; Campbell, P.; Hare, L.; Couture, P. Sub-cellular partitioning of cadmium, copper, nickel and zinc in indigenous yellow perch (Perca flavescens) sampled along a polymetallic gradient. Aquat. Toxicol. 2006, 77, 178-189.

(64) Racine, K. Etude de la Répartition Subcellulaire des Élements du Groupe Platine et des Terres rares Chez l'algue Verte Chlamydomonas reinhardtii; Université du Québec, Institut National de la Recherche Scientifique, 2016.

(65) Hopkin, S. P. Critical concentrations, pathways of detoxification and cellular ecotoxicology of metals in terrestrial arthropods. Funct. Ecol. 1990, 4, 321-327.

(66) Jakubek, L. M.; Marangoudakis, S.; Raingo, J.; Liu, X.; Lipscombe, D.; Hurt, R. H. The Inhibition of Neuronal Calcium Ion Channels by Trace Levels of Yttrium Released from Carbon Nanotubes. Biomaterials 2009, 30, 6351-6357.

(67) Gao, Y.; Zeng, F.; Yi, A.; Ping, S.; Jing, L. Research of the Entry of Rare Earth Elements $\mathrm{Eu}^{3+}$ and $\mathrm{La}^{3+}$ into Plant Cell. Biol. Trace Elem. Res. 2003, 91, 253-265.

(68) Korotkov, S. M.; Sobol', K. V.; Shemarova, I. V.; Furaev, V. V.; Nesterov, V. P. Comparative Study of $\mathrm{Y}^{3+}$ Effect on CalciumDependent Processes in Frog Cardiac Muscle and Mitochondria of Rat Cardiomyocytes. J. Evol. Biochem. Physiol. 2016, 52, 196-203. 